\title{
KALEIDOSCOPE
}

\author{
Mónika Ganczer*
}

\section{European Round of Manfred Lachs Space Law Moot Court Competition, 29-30 April 2010, Győr}

The European Regional Round of Manfred Lachs Space Moot Court Competition was held at Széchenyi István University Deák Ferenc Faculty of Law and Political Sciences in Győr, Hungary from 29 to 30 April 2010. The European Centre for Space Law (ECSL), together with the International Institute of Space Law (IISL), organises each year the European Regional Round of the Manfred Lachs Space Law Moot Court Competition. This year, the Széchenyi István University Deák Ferenc Faculty of Law and Political Sciences hosted and the Hungarian Branch of International Law Association supported the organizing. The European Regional Round has been held annually since 1993, with teams participating from all parts of Europe.

The Space Law Moot Court Competition began in 1992, when the U.S. members of the International Institute of Space Law invited the George Washington University and the American University each to send two teams to participate in a moot court competition in conjunction with the International Astronautical Congress. In 2003, the European Regional Round was created, and after the death of Judge Manfred Lachs, ${ }^{1}$ former President of the International Court of Justice (and former Judge of the competition) the competition was renamed in his honour and memory. In 2000, the Asia-Pacific Regional Round was created

* Assistant lecturer, Széchenyi István University Faculty of Law and Political Sciences, H-9026 Győr, Egyetem tér 1.

E-mail: ganczermonika@yahoo.com

1 Manfred H. Lachs (April 21, 1914 Stanisławów, Austria-Hungary [now Ivano-Frankovsk, Ukraine] - January 14, 1993, The Hague, Netherland) was a Polish lawyer and diplomat who profoundly influenced the development of international law. He attended the Krakow Jagiellonian University where he earned a doctorate in Laws (1937). After his studies, he started working for the Consular Academy of Vienna and afterwards in the London School of Economics before the outbreak of World War II. Lachs was drafted in the army and throughout his military service he was advisor to the Polish government. Before his career turned toward international laws, he filled many judiciary posts in the Polish government such as Poland's Foreign Affairs director of the Department of treaties and legal jurisdiction between 1947 and 1960 then prime minister's special advisor between 1960 and 1967. During the Paris Peace conference of 1946, Lachs stood for his country as a delegate. He became a professor of international law at the University of Warsaw in 1952 and served as a member of the Polish delegation of the General Assembly of the United Nations. Afterwards, he became a judge on the International Court of Justice in 1967 and eventually became one of the longest-serving judges there, working until 1993. During his stay as a judge to the International Court, he presided the Court from 1973 to 1976. He wrote The Law of Outer Space: An Experience in Contemporary Law Making in 1972, which contributed to the development of the law of outer space. After his death, the Manfred Lachs Space Law Moot Court Competition was named in his honour. 
and, by 2008, over 50 law schools now participate in the Manfred Lachs Space Law Moot Court Competition each year.

In August 2009, as each year, selected scholars of space law had produced the moot problem that was released to universities and posted on the website of the Manfred Lachs Space Law Moot Court Competition. Law schools in each region then registered for the Regional Rounds. To participate in the competition, 2 to 3 committed law students interested in expanding their knowledge of international law and gain valuable international mooting experience were needed. Participating groups have submitted written memorials for both the Applicant and the Respondent on the moot problem in February. Regional Rounds are usually held between March and May, with the Asia-Pacific Regional Round usually held in Sydney, Australia, the North America Regional Round in Washington, D.C., and the European Regional Round hosted in various cities.

Other Regional Rounds have already been organized at the beginning of April. The 2010 North American Regional Round was held on 10 April 2010 at the Georgetown University Law Center, Washington, D.C. Each year, the American Association of IISL Members organises the North American Regional Round of the Manfred Lachs Space Law Moot Court Competition. Competitors were from the United States and Canada and the top two teams were George Washington University and Georgetown University. The George Washington University won the final round and was also awarded the Best Brief Award, although Georgetown won the F. Kenneth Schwetje Best Oralist Award. The Asia Pacific Regional Rounds have always been the largest region in the competition. The Indian Space Research Organisation (ISRO) funded the annual Indian National Funding Rounds in India to assist teams to compete in the Asia Pacific Regional Round each year. This year the Indian Domestic Funding Round was held in Bangalore, India on 19-21 February. The West Bengal National University of Juridical Sciences, Kolkata defeated the home team National Law School of India University, Bangalore in the finals, but National Law School of India University bagged the best memorial prize. The 2010 Asia Pacific Regional Rounds were held in Sydney, Australia between 13 and 17 April. Finalists were the teams of the National University of Singapore and the National Law School of India University, Bangalore, India. The National University of Singapore won the final round in close contest and obtained the Alexis Goh Memorial Trophy.

The European Round was opened by Prof. Sergio Marchisio, Chairman of the European Space Agency European Centre for Space Law and Dr. Gábor Sulyok, Vice-dean for academic affairs of Széchenyi István University Deák Ferenc Faculty of Law and Political Sciences.

The 2010 moot problem is the case concerning Suborbital Tourism, Definition of Outer Space and Liability (Aspirantia v. Republica), ${ }^{2}$ revolving around the edge of space, liability and rescue commitment of states. The jurisdiction of the International Court of Justice comprises by Special Agreement of the two states, jointly notified to the Court according to Article 36(1) of the Statute. In the Special Agreement the Parties agreed the following facts.

The space tourism company Startours is incorporated in Aspirantia because of two reasons: the favourable tax climate for start-up companies, and the fact that it has no national space licensing regulations governing private or commercial space flights. Startours

2 The 2010 Moot Problem can be downloaded from <http://www.spacemoot.org/acrobat/ prob2010.pdf>. 
has developed an experimental passenger spacecraft Starflight-1 that is designed to take off from a specially-adapted and refurbished carrier-aircraft flying high above the high seas. The private charter airline whose aircraft is used for this purpose is owned and controlled by private citizens of Zerbica. Startours offers suborbital flights to an altitude of $112 \mathrm{~km}$. During the maiden flight of Starflight-1 after separation from the carrier aircraft, Starflight-1 successfully blasted off and, after having reached an altitude of $93 \mathrm{~km}$, returned to Earth using its wings for stabilisation. However, on its descent from that altitude it was struck by a piece of metal, loss of cabin pressure and the immediate death of the two of the three passengers and the co-pilot. All of the victims wore the pressurised suits, but they had taken off his headgear. The captain had insufficient authority to compel them to put their helmets back on, but him and the remaining female passenger did not remove their headgear. Consequently, the captain and the remaining passenger survived, though seriously injured, and landed in Aspirantia. The Minister of Aspirantia announced his plans to draft national space legislation to regulate space activities, with particular attention to the problem of space debris.

In the meantime, Startours began an investigation and found a metal capsule with the inscription "father" and a serial number, came from a separate launch that took place on the same day by Stationride Corporation, a private company licensed by Kingdom of Republica. Stationride operates flights to a permanent national space station orbiting the Earth at $350 \mathrm{~km}$ above mean sea level. Stationride, which uses Stationferry to carry scientists and supplies to the Republican space station, obtained permission from the Government of Republica to offer rides to private individuals, even an extra-vehicular space walk can be arranged. Stationrider recently contracted with Ashes Corporation, a funeral services company incorporated in Republica, to carry a small container containing capsules each filled with 5 grams of human ashes, to be placed into low earth orbit. Although environmentalists, astronomers and space scientists in Republica have protested against this way of using and polluting orbital space, the Republican Space Agency saw no reason to forbid this launch and did not inform other nations about this payload and its destination. Its reasoning was that the low "graveyard orbit" used for this purpose guaranteed that the container with the capsules would not interfere with any active space objects in orbit and would, through atmospheric drag, fall back to earth within 15 years and disintegrate in the atmosphere, causing no harm to the Earth or pose a risk to orbital space activities. Timothy L. Ash was onboard Stationferry and he had made extra payments for an extra-vehicular spacewalk. With permission from the captain of the Stationferry, Alfons Linke to whom Mr. Ash paid a handsome amount of money, Mr. Ash hid one of the cremain capsules in his spacesuit that contained the ashes of his father-in-law that he intended to personally release into space, which impacted on Starflight-1. Startours began a lawsuit against Stationrider under the Space Activities Act and against the Republican Space Agency under administrative law in the Federal Court of Republica, claiming full compensation from both, jointly and severally, for the destruction of Starflight- 1 and the death and injuries to the crew and flight participants onboard.

In the meantime, a return flight of the Stationferry from the Republican space station to the Earth suffered a malfunction during its descent through the atmosphere and the spacecraft was forced to declare an emergency and land the spacecraft at the nearest aerodrome with a long enough runway, which turned out to be an air force base in Aspirantia. As a safety precaution, the Stationferry released the fuel into a large lake that Captain Linke mistook for the ocean and landed safely. The fuel caused serious environmental damage to some protected natural habitats of rare animals, with cleanup costs. It was revealed that Captain Linke was piloting the spacecraft and Dr. François Vienet, the Director-General of 
the Republican Space Agency, was onboard as a private space flight participant. As a result of the domestic and international media attention surrounding the accident of Starflight-1, the Government of Aspirantia arrested Dr. Vienet and Captain Linke on charges of manslaughter of the victims onboard Starflight-1 and breaches of the environmental laws of Aspirantia but released the Stationferry and all other crew and passengers onboard to the Government of Republica. Significant costs were incurred by the Aspirantian Government in relation to the care and repatriation of the remaining crew and passengers of Stationferry and the return of the spacecraft.

Federal Court of Republica dismissed the claims against both defendants on the basis that: (i) the Republican Space Agency has fulfilled its obligations as the licensing authority for the Government of Republica and cannot be blamed for any subsequent behaviour on the part of Stationrider; and (ii) after hearing testimony from an independent aerospace engineer, the Court accepted his evidence that the technical specifications of Starflight-1 and its carrier-aircraft showed that Starflight-1 was not sufficiently powerful or advanced to ever reach an altitude of $100 \mathrm{~km}$.

The two countries agreed to submit their dispute to the International Court of Justice to decide the following questions: (i) whether Republica is responsible for the acts and omissions of Stationrider and is liable for the loss and damage suffered by Aspirantia in relation to the loss of Starflight-1 or Aspirantia acted unlawfully in arresting and charging Captain Linke and Dr. Vienet and must withdraw the charges against them and return them immediately to Republica; (ii) whether Republica is liable to pay the cleanup, recovery and return costs incurred by Aspirantia as a result of the emergency landing by Stationferry; or Republica is not liable for the damage sustained by Starflight-1; and (iii) whether Aspirantia acted lawfully in arresting and charging Captain Linke and Dr. Vienet or Republica is not liable to pay Aspirantia for cleanup, recovery and return costs of the Stationferry, its passengers and its crew.

The nine competitor teams of the European oral pleadings arrived from the United Kingdom, Germany, Poland, Italy, The Netherlands, Russia representing the University of Silesia, Katowice; University of Cologne, Köln; The Honourable Society of Inner Temple, London; University of Genoa; Leiden University; University of Aberdeen Law School; University of Lueneburg; John Paul II Catholic University of Lublin and the Law Faculty of the Peoples' Friendship, Moscow. Teams contented in 9 preliminary rounds as agents of the Applicant and the Respondent state on 29 April. After totalizing the scores of memorials and oral pleading scores of the teams, Prof. Sergio Marchisio announced the finalists, and the coin toss decided that the University of Cologne (Ms. Lisa Kûpers, Mr. Erik Pellander and Mr. Martin Reynders) as Applicant and the Leiden University (Ms. Sotiria Tsoukala, Mr. Christopher Johnson and Ms. Ana Cristina Rosa) as Respondent should compete in final round.

The Final Round was held on 30 April. The team of University of Cologne has won the European Round, defeating Leiden University. The team of University of Cologne was contest the World Finals to be held in October 2010 in Prague, Czech Republic.

The winner of each region will gather for the 19th World Finals Finals of the Manfred Lachs Space Law Moot Court Competition between 27 September and 1 October, held in conjunction with the International Astronautical Congress and the International Institute of Space Law Colloquium on the Law of Outer Space in Prague, Czech Republic. Participants of the competition are encouraged to attend the International Astronautical Congress, especially as there are several policy and law sessions each year that may be of interest. The world semi-final will be held on 28 September 2010, with the world final, to be judged by three sitting members of the International Court of Justice, to be held on 30 September 
2010. The two teams with lower-ranked memorial scores, as determined by an independent judging panel of scholars, will compete in a semi-final. The following prizes are awarded at the world finals each year: Manfred Lachs Trophy (awarded to the winning team in the world final); Eilene M. Galloway Award (awarded to the team with the best combined score for their memorials); Sterns and Tennen Award (awarded to the best individual oralist in the world final); Lee Love Award (awarded to the members of the winning team in the world final). 